\title{
Acute Abdomen in a Patient with Overt Hypothyroidism: A Case Report
}

\author{
Ağır Hipotiroidili Hastada Akut Batın: Bir Olgu Sunumu
}

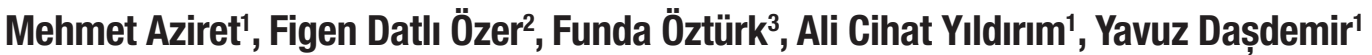 \\ ${ }^{1}$ Kars State Hospital, Department of General Surgery, Kars, Turkey; ${ }^{2}$ Kars State Hospital, Department of Anesthesiology and Reanimation, \\ Kars, Turkey; ${ }^{3}$ Kars State Hospital, Department of Endocrinology, Kars, Turkey
}

\begin{abstract}
Acute abdomen and hypothyroidism are two commonly encountered conditions in clinical practice, individually. However, simultaneous occurence of both is an infrequent and crucial condition which requires a multidisciplinary approach.

We present the management of a 69 year-old, obese woman diagnosed with clinical symptoms of severe hypothyroidism and acute appendicitis. She was operated under general anesthesia and discharged from hospital after postoperative intensive care unit follow up.
\end{abstract}

Key words: abdomen; acute; appendicitis; critical care; hypothyroidism

\section{ÖZET}

Akut batın ve hipotiroidizm klinik pratikte sık rastlanan iki ayrı durumdur. Ancak hipotiroidinin eșlik ettiği akut batın sık rastlanmayan, multidisipliner yaklașım gerektiren zor bir durumdur.

Bu yazıda ağır hipotiroidi ve akut apandisiti olan 69 yașındaki obez kadının sağaltımı sunuldu. Genel anestezi altında ameliyat edilen hasta postoperatif yoğun bakım ünitesi takibinden sonra taburcu edildi.

Anahtar kelimeler: karın; akut; appendisit; kritik bakım; hipotiroidi

\section{Introduction}

Association of severe thyroid diseases with surgical emergencies is rarely encountered in clinical practice ${ }^{1}$. The condition is crucial and occurs in patients with extremely malfunctioning thyroid glands and may be life-threatening ${ }^{2-4}$. Appendectomy for appendicitis is the most commonly performed emergency operation

Uzm. Dr. Mehmet Aziret, Kars Devlet Hastanesi, Genel Cerrahi Bölümü, Kars, Türkiye, Tel.4742125668/3119Email.mbmtaziret@gmail.com Geliş Taribi: 28.10.2014 • Kabul Taribi: 14.11.2014 worldwide and early surgical treatment is the gold standard treatment option ${ }^{5}$. Herein, we presented an appropriate management of acute abdominal surgical disease superimposed on overt hypothyroidism.

\section{Case Report}

A 69 year-old, obese (body mass index was $32 \mathrm{~kg} / \mathrm{m}^{2}$ ) woman was evaluated in the emergency room. She had abdominal pain, constipation, loss of appetite and nausea. The symptoms had begun two days ago.

The woman was confused (Glasgow Coma Scale: $14 / 15$; eye response: 4 , motor response: 6 , verbal response: 4) and had slow-relaxing reflexes, therefore her medical history was taken from her son. She had no known disease or past surgery, gave vaginal births to nine children.

On physical examination, her facial skin was rough, wrinkled and dry, also her hair was poured. Abdominal wall was distended and defensive. In addition, there was rebound tenderness in the right lower quadrant. Laboratory examination revealed a white blood cell count, hemoglobin, creatinine, urea and CRP values of $16.4 \mathrm{~L}^{-1}, 10.1 \mathrm{~g} / \mathrm{dL}, 1.34 \mathrm{~g} / \mathrm{dL}, 66 \mathrm{mg} / \mathrm{dL}$, and 12.6 $\mathrm{mg} / \mathrm{dL}$, respectively.

Abdominal X-ray was unremarkable. On computed tomography (CT) scan dirty mesenteric fat plans due to inflammation in the right lower quadrant were determined in addition to a $35 \mathrm{~mm}$ hyper-dense mass in the left liver lobe (Fig. 1).

An emergent exploratory laparotomy with a median abdominal incision was performed under general anesthesia. During the beginning of the anesthesia induction, the patient had deep bradycardia and hypotension 


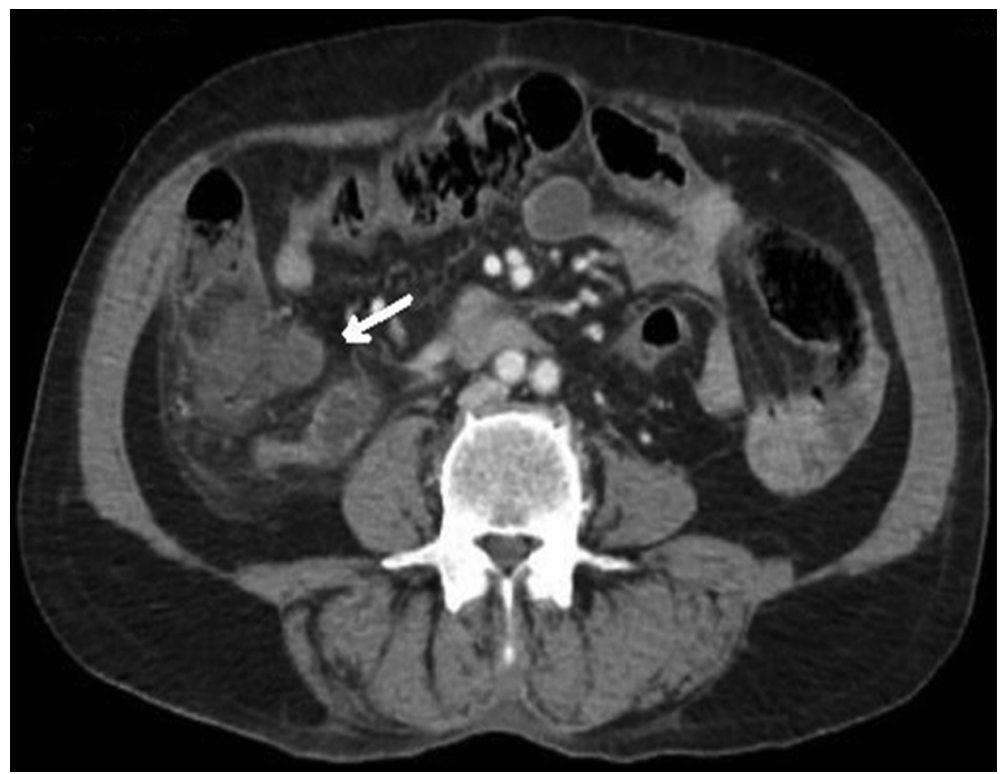

Figure 1. Appearance of dirty mesentery in the right lower quadrant (arrow).

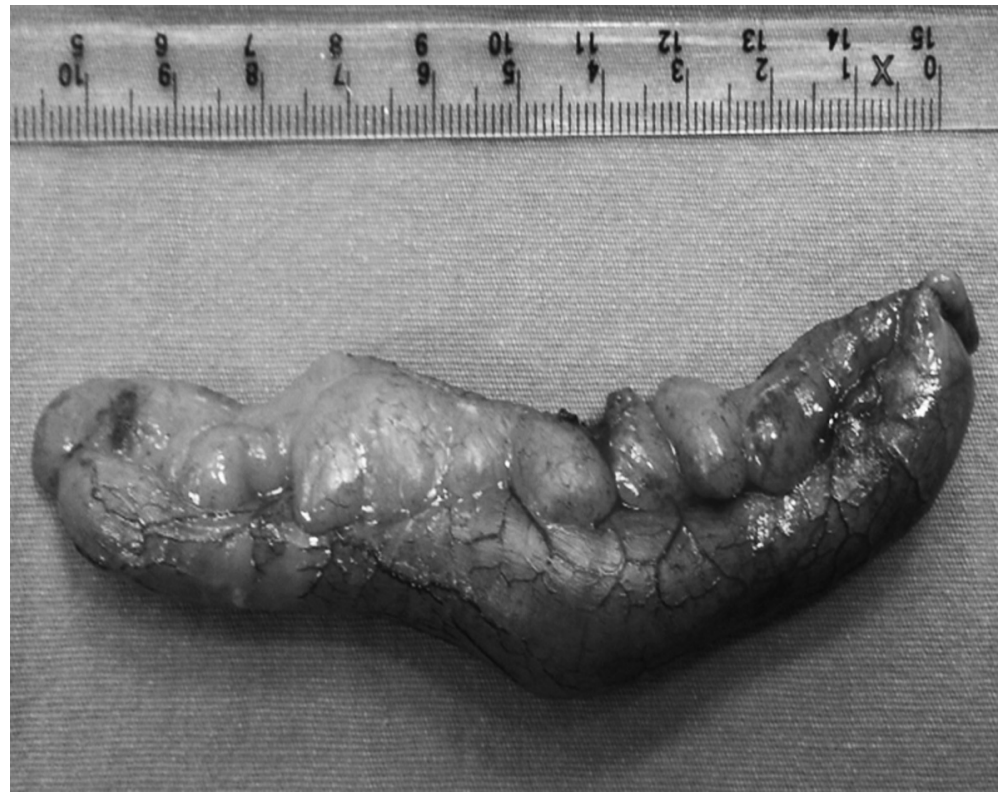

Figure 2. Appendectomy specimen.

and needed $1 \mathrm{mg}$ intravenous atropine, intense fluid replacement and the administration of vasoconstrictive agent infusion throughout the operation.

Abdominal exploration revealed an edematous and inflamed appendix with $200-300 \mathrm{ml}$ of serous fluid around it. The remaining intra abdominal structures were normal in appearance and color. Following appendectomy (Fig. 2), the mass in the liver (type 5 hydatid cyst) was palpated; however emergent surgical treatment was not necessary in that case. A drain was placed in pouch of Douglas and abdominal wall was closed anatomically.

We tried to awake the patient from general anesthesia, however the depth of spontaneous breathing and consciousness could not be maintained at satisfactory levels, thus the patient was transferred to the intensive care unit and connected to a mechanical ventilator. Intravenous methylprednisolone was given for suspicious adrenal gland insufficiency, because the patient was hypoglycemic in early postoperative phases of the operation. 
Table 1. The laboratory findings on postoperative day 1

\begin{tabular}{lcc}
\hline Laboratory test & Measured value & Normal range \\
\hline Free-T3 & $0.78 \mathrm{pg} \cdot \mathrm{mL}^{-1}$ & $2.5-3.9 \mathrm{pg} \cdot \mathrm{mL}^{-1}$ \\
Free-T4 & $0.1 \mathrm{ng} \cdot \mathrm{mL}^{-1}$ & $0.54-1.24 \mathrm{ng} \cdot \mathrm{mL}^{1}$ \\
TSH & $0.81 \mathrm{mlU} \cdot \mathrm{L}^{-1}$ & $0.34-5.60 \mathrm{mlU} \cdot \mathrm{L}^{-1}$ \\
Prolactin & $0.59 \mu \mathrm{g} \cdot \mathrm{L}^{-1}$ & 2.7 to $19.64 \mu \mathrm{g} \cdot \mathrm{L}^{-1}$ \\
Growth Hormone & $<0.030 \mathrm{ng} \cdot \mathrm{dL}^{-1}$ & 0 to $9.88 \mathrm{ng} \cdot \mathrm{dL}^{-1}$ \\
FSH & $2.04 \mathrm{mlU} \cdot \mathrm{mL}^{-1}$ & 16.74 to $113.6 \mathrm{mlU} \cdot \mathrm{mL}^{-1} \mathrm{for} \mathrm{PMP*}$ \\
LH & $0.78 \mathrm{mlU} \cdot \mathrm{mL}^{-1}$ & 10.87 to $58.64 \mathrm{mlU} \cdot \mathrm{mL}^{-1} \mathrm{for} \mathrm{PMP*}$ \\
Estradiol & $3 \mathrm{pg} \cdot \mathrm{mL}^{-1}$ & $20-40 \mathrm{pg} \cdot \mathrm{mL}^{-1}$ \\
ACTH & $9.6 \mathrm{pg} \cdot \mathrm{mL}^{-1}$ & 10 to $60 \mathrm{pg} \cdot \mathrm{mL}^{-1}$ \\
Cortisol & $8.4 \mathrm{~g} \cdot \mathrm{dL}^{-1}$ & $6.7-22.6 \mathrm{~g} \cdot \mathrm{dL}^{-1}$ \\
\hline
\end{tabular}

*PMP, post-menopausal period.

The laboratory findings of the patient were summarized in Table 1 .

Stress dose intravenous methylprednisolone was started upon the endocrinology specialist's suggestion. Hemodynamic clinical picture and blood glucose level returned to normal levels, and thus, the vasoconstrictive agent was discontinued after gradual dose decrease.

The woman gained consciousness and was weaned from the mechanical ventilator on the second postoperative day. Levothyroxine at a dose of $25 \mu \mathrm{g}$ via nasogastric tube was added to the treatment after three days of metilprednisolone use and then dose was increased day by day.

The intestinal gas was discharged after 72 hours and following the removal of the nasogastric tube oral regimen was started. An elective pituitary magnetic resonance imaging (MRI) was performed and a consultation was requested from neurosurgery department. MRI revealed that suprasellar cistern was herniated into the sella and pressed the pituitary gland. The diagnosis was empty sella as the cause of central hypothyroidism.

The woman was discharged on postoperative ninth day with a prescription containing daily doses of oral levothyroxine and prednisolone.

The pathological examination of the operative specimen was reported as acute phlegmoneus appendicitis. The long term follow up the patient has been uneventful (Fig. 3).

\section{Discussion}

Thyroid hormones have multiple functions and affect almost all of the body. They have important role in neuromuscular stimulation, cardiac contractility and vascular tone, electrolyte balance, regulation of menstrual cycle and skin tonus ${ }^{1,3,6}$.

Hypothyroidism is a condition characterized by inadequate production of thyroid hormones or by insufficient effect on the target organs. It may occur primarily or secondarily ${ }^{6,7}$. Hashimoto's thyroiditis, thyroidectomy,

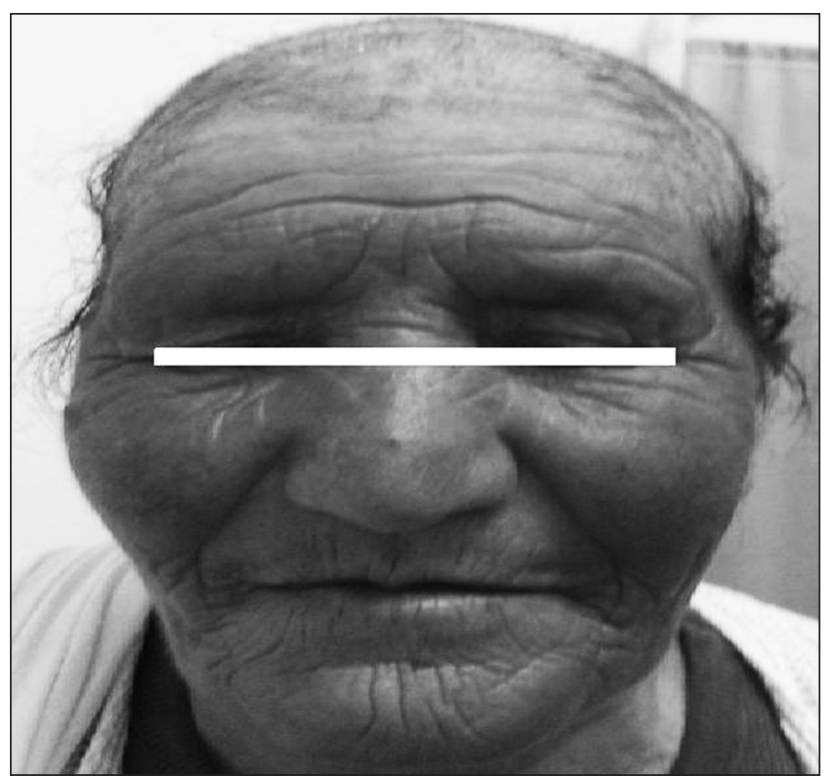

Figure 3. The appearance of patient on postoperative day nine. 
sub-acute thyroiditis and drugs (antithyroid drugs, lithium) are causes of primary hypothyroidism.

Hashimoto's thyroiditis is the most common inflammatory disorder of thyroid gland and leading cause of hypothyroidism ${ }^{4,6}$. In Framingham study, the prevalence of hypothyroidism was $4.4 \%$ and increased with age $(>60 \text { years })^{8}$. In addition, hypothyroidism was more frequent in women (5.9\%) than men $(2.3 \%)^{8}$.

A review published by the American College of Physicians in 1998 estimated that depending on the population studies, overt hypothyroidism was seen in $2 \%$ of women over 69 years and 0.1 of men over 59 years'. Our patient was a 69 year-old woman.

Hypothyroidism includes a broad spectrum of symptoms ranging from symptomless to serious cardiac and central nervous system diseases. The symptoms of abdominal pain, constipation, dyspepsia, hair loss, skin flaking, sleepiness and confusion, bradycardia, and electrolyte imbalances may be seen. The rates of mortality and morbidity increase with advanced severity of the symptoms $\mathrm{s}^{2,4,6,10-12}$. Our patient had most of the above-mentioned symptoms.

A study published by the Yaylalı et al. implicated hypothyroidism as a cause of dyspepsia as a result of reduced gastro-esophageal motility ${ }^{10}$. In addition, Vantrappen et al. determined development of a small intestinal bacterial overgrowth (SIBO) that was depended on intestinal dysmotility in hypothyroidism. Moreover, the symptoms and signs are aggravated with severe hypothyroidism ${ }^{13}$. The gastrointestinal dysmotility accompanying hypothyroidism may significantly complicate the situation and alter the management of the postoperative patient. Atony and hypomotility of the gastrointestinal tract are well described entities in these patients who may develop postoperative paralytic or myxedema ileus ${ }^{14}$. Similarly, Rodrigo et al. reported a case with acute kidney injury and paralytic ileus, probably as a result of associated hypothyroidism ${ }^{15}$. Abdominal pain and constipation were superior symptoms in our patient before the diagnosis of acute appendicitis; however the situation was not complicated with an ileus in pre- or post-operative period.

The diagnosis of acute appendicitis still represents one of the most challenging emergency problems of surgery ${ }^{13,15}$. The patients usually admit to the hospital with appetite loss, nausea and abdominal pain. The diagnosis may cause confusion in elderly patients with metabolic diseases ${ }^{1416}$. Physical examination, laboratory findings and abdominal CT helps in diagnosis. There is always muscular defense and rebound tenderness in right lower quadrant and immediate open or laparoscopic appendectomy is gold standard for treatment of acute appendicitis ${ }^{16,17}$.

Low levels of free-T3, T4 and high TSH are determined in primary hypothyroidism while in secondary hypothyroidism, a low or normal level of TSH, which is expected to increase logarithmically due to decreased levels of free-T3/ T4, are detected ${ }^{9,17}$. Our patient had a normal value of TSH, but low levels of free-T3 and T4 and a severe clinical picture of hypothyroidism. The levels of prolactin, growth hormone, ACTH were all lower than normal. The cortisol level also seemed normal according to laboratory cut-off values. In addition, FSH and LH levels were under normal levels. The free-T4 is the treatment guiding parameter for secondary hypothyroidism while it is TSH for primary hypothyroidism. Thus, it is important to reveal the underlying cause and the type of hypothyroidism to manage the disease. A history of thyroid surgery, excessive bleeding in the previous births or multi parity, intracranial mass or neck radiation therapy should be investigated. In addition, the presence of antibodies against thyroid hormones and thyroid nodules may cause hypothyroidism ${ }^{18,19}$.

In patients with severe hypothyroidism, reduced cardiac output and blood volume, abnormal baroreceptor function, decreased hepatic metabolic function and diminished renal extraction may occur and the sensitivity to anesthetic and sedative agents may develop ${ }^{20}$. Sedative, analgesic and hypnotic agents may yield a myxomatous coma in severe hypothyroidism ${ }^{21}$. On the other hand, level of cortisol should be measured for concomitant adrenal insufficiency ${ }^{22}$. Our patient had deep bradycardia and hypotension following anesthesia induction and could not awaken from general anesthesia; that's why she was followed up in intensive care unit and connected to a mechanical ventilator. Both the hypothyroidism and hypocortisolemia were the possible causes.

The cornerstones in the treatment of overt hypothyroidism are the relieving of symptoms and avoiding progression of disease to myxomatous coma ${ }^{22}$. Severe hypothyroidism is usually treated by oral replacement of levothyroxine which is classically administered as a once-daily dose of $1.6 \mathrm{mg} / \mathrm{kg}$ (or 25-50 mg daily). Levothyroxine should be increased by controlling the levels of $\mathrm{TSH}^{22,23}$. The initial dose in elderly patients 
with ischemic heart disease should be $25 \mathrm{mg}$ daily ${ }^{24}$. Levels of free T3 and T4 should be maintained in normal ranges in patients requiring elective surgery. During emergency surgery regional anesthesia may be preferred. Thoracic epidural anesthesia may be an option in upper gastrointestinal surgeries to cause less postoperative pain and morbidity ${ }^{24}$.

\section{Conclusion}

The management of association of severe hypothyroidism and an acute abdominal surgical disease requires a multidisciplinary approach and an advanced hospital facilities.

\section{References}

1. Kearney T, Dang C. Diabetic and endocrine emergencies. Postgrad Med J 2007;83:79-86.

2. Pearce EN, Roti E, Papi G. Massive goiter. Thyroid 2006;16:621-2.

3. Papi G, Corsello SM, Pontecorvi A. Clinical concepts on thyroid emergencies. Frontiers in Endocrinology 2014;5:102.

4. Bhansali A, Sreenivasulu PP, Chattopadhyay A, et al. Juvenile primary hypothyroidism presenting as acute abdomen and later with vision loss. The Endocrinologist 2004; 14:229-32.

5. Erdem H, Çetinkünar S, Daş K, et al. Appendicitis scores for diagnosis of acute Appendicitis. World J Gastroenterol 2013;19:9057-62.

6. Qari F. Hypothyroidism in Clinical Practice. J Family Med Prim Care 2014;3:98-101.

7. Patil AD. Link between hypothyroidism and small intestinal bacterial overgrowth. Indian J Endocrinol Metab 2014;18:307-9.

8. Sawin CT, Castelli WP, Hershman JM et al. The aging thyroid. Thyroid deficiency in the Framingham Study. Arch Intern Med 1985;145:1386-8.

9. American College of Physicians. Clinical guideline, part 1. Screening for thyroid diseases. Ann Intern Med 1998;129:141-3.

10. Yaylali O, Kirac S, Yilmaz M et al. Does hypothyroidism affect gastrointestinal motility? Gastroenterol Res Pract 2009; Article ID 529802, 7 pages doi:10 1155/2009/529802.
11. Almandoz JP, Gharib H. Hypothyroidism: Etiology, diagnosis, and management. Med Clin North Am 2012;96:203-21.

12. Ciobanu L, Dumitrascu DL. Gastrointestinal motility disorders in endocrine diseases. Pol Arch Med Wewn 2011;121:129-36.

13. Vantrappen G, Janssens J, Hellemans J et al. The interdigestive motor complex of normal subjects and patients with bacterial overgrowth of the small intestine. J Clin Invest 1977;59:1158-66.

14. Wysocki AP, Allen J, Rey-Conde T, et al. Mortality from acute appendicitis is associated with complex disease and comorbidity. ANZ J Surg 2014 Aug 21. doi:10 1111/ans 12829.

15. Rodrigo C, Gamakaranage CS, Epa DS, et al. Hypothyroidism causing paralytic ileus and kidney injury -case report. Thyroid Res 2011;4:7.

16. Ozkan S, Duman A, Durukan P, et al. The accuracy rate of Alvarado score, ultrasonography, and computerized tomography scan in the diagnosis of acute appendicitis in our center. Niger J Clin Pract 2014;17:413-8.

17. Cipe G, Idiz O, Hasbahceci M, et al. Laparoscopic versus Open Appendectomy: Where Are We Now? Chirurgia 2014;109:518-22.

18. Lindsay RS, Toft AD. Hypothyroidism. Lancet 1997;349:413-6.

19. Topliss DJ, Eastman CJ. Diagnosis and management of hyperthyroidism and hypothyroidism. Med J Aust 2004;180:186-93.

20. Wall RT. Endocrine diseases. In: Hines, Marschall, editors. Stoelting's Anesthesia and Co. Existing Disease 5th ed. Philadelphia (USA): Churchill Livingstone; 2012. p.416-27.

21. Anand TT, Shrirang R, Ravi M, et al. A case of subacute intestinal obstruction with overt hypothyroidism in stupor scheduled for emergency laparotomy. Indian J Anaesth 2014;58:347-9.

22. Burrell M, Cronan J, Megna D, et al. Myxedema megacolon. Gastrointest Radiol 1980;5:181-6.

23. Isabela MB, Rodrigo DO, Paulo AL, et al. Hypothyroidism in the elderly: diagnosis and management. Clin Intervent Aging 2012;7:97-111.

24. Baskin HJ, Cobin RH, et al. American association of clinical endocrinologists medical guidelines for clinical practice for the evaluation and treatment of hyperthyroidism and hypothyroidism endocrine practice. Endocr Pract 2002;8:457-69. 